Original Research Article

\title{
Effect of fluoxetine and paroxetine on intestinal motility
}

\author{
Ayesha Afzal ${ }^{1 *}$, Mahjabeen Sharif ${ }^{2}$, Ammara Khan $^{3}$, Bushra Tayyaba Khan ${ }^{2}$, Iffat Ara ${ }^{1}$
}

${ }^{1}$ Department of Pharmacology, Wah Medical College (UHS), Wah, Cantt, Pakistan

${ }^{2}$ Department of Pharmacology, Army Medical College, Rawalpindi, Pakistan

${ }^{3}$ Department of Pharmacology, Gujrat Medical College, Gujrat, Pakistan

Received: 27 November 2017

Revised: 05 January 2018

Accepted: 09 January 2018

*Correspondence to:

Dr. Ayesha Afzal,

Email: dr.ayeshaafzal@

hotmail.com

Copyright: (C) the author(s), publisher and licensee Medip Academy. This is an openaccess article distributed under the terms of the Creative Commons Attribution NonCommercial License, which permits unrestricted noncommercial use, distribution, and reproduction in any medium, provided the original work is properly cited.

\begin{abstract}
Background: Serotonin (5-HT) is a biogenic amine that functions as a neurotransmitter of sensorimotor functions in the digestive tract. Te role of 5-HT agents in the modulation of lower gastrointestinal function. Selective serotonin reuptake inhibitors (SSRIs) are of potential benefit in functional gastrointestinal diseases although formal evidence is lacking. Apart from central effects, they may have peripheral. The present study was carried out to find out the possible effects of fluoxetine and paroxetine on gastrointestinal smooth muscles of rabbit as they cause severe nausea and vomiting initially.

Methods: Experimental study design. Power lab (USA) for recording the contractions of ileal smooth muscle of rabbit in response to serotonin, fluoxetine and paroxetine.

Results: The percent responses with serotonin, fluoxetine and paroxetine were $100,10.53$, and 4.75 percent respectively.

Conclusions: SSRIs (fluoxetine and paroxetine) were unable to enhance the serotonergic transmission in vitro inturn decreases the qualitative response.
\end{abstract}

Keywords: Diarrhea, Fluoxetine, Gastrointestinal tract, Paroxetine, Power lab, Serotonin

\section{INTRODUCTION}

There are many neurotransmitters which are involved in the pathopysiology of nausea and vomiting. The most common are serotonin, dopamine and substance $\mathrm{P}$ (Neurokinin 1). Their receptors are present in high concentration in dorsal vagal complex, area prostrema and gastrointestinal tract.

Deficiencies or fluctuation in the levels of serotonin, norepinephrine and dopamine is now thought to be the basis for the etiology of depression. Several clinical studies suggested that by targeting the specific serotonin receptors with selective agonist or antagonist not only improves the efficacy but also reduces time required for the therapeutic effect of antidepressants to appear Aside from depression SSRI's are also prescribed worldwide for anxiety disorder, various types of eating disorders, acute attack of migraine, chemotherapy induced nausea and vomiting, obsessive compulsive disorders, pain due to neuropathy, fibromyalgia's, panic disorder and schizophrenia. ${ }^{1}$ 
The primary pharmacological activity of SSRIs is inhibition of the serotonin transporter (SERT) which is responsible for the reuptake of serotonin $(5-\mathrm{HT})$ from the extracellular space back into the nerve terminals that release it. Inhibition of this transport alters the spatiotemporal dynamics of serotonin signalling such that activity in the serotonergic neuron causes greater and more prolonged increases in extracellular serotonin than would normally occur. ${ }^{2}$

Due to this nausea and vomiting are common adverse effects of these therapeutic drugs. Such symptoms are more often due to CNS effects than to direct toxic effects on the gastrointestinal tract (GIT). Drugs may cross the blood-brain barrier and activate the chemoreceptor trigger zone in the brainstem, which contains cells that are responsive to cholinergic, dopaminergic and serotonergic stimulation. Binding of serotonin to its receptors stimulate the chemoreceptor trigger zone (CTZ) and vomiting centre (VC) in the medulla. Once activated the vomiting centre modulate the efferent transmission to the respiratory vasomotor and salivary center. Vomiting center also modulate impulses to the abdominal muscles, diaphragm, and esophagus resulting in emesis. ${ }^{3}$

The present study was carried out to explore the underlying mechanism of excessive nausea and vomiting produced by selective serotonin reuptake inhibitors, we observed the effects of fluoxetine and paroxetine on ileal smooth muscles of rabbits in vitro and also observed that which among these two has better tolerability against nausea and vomiting. So serotonin-mediated intestinal activity was taken as control in our research study. ${ }^{4}$

\section{METHODS}

This experimental study was carried out in Multidisciplinary Lab Army Medical College Rawalpindi, from May 2016 to July 2016.

\section{Chemicals}

Serotonin Carnitine Sulfate, fluoxetine hydrochloride and paroxetine hydrochloride were purchased from local market. All the solutions and dilutions $\left(10^{-9}\right.$ to $\left.10^{-6} \mathrm{M}\right)$ were prepared fresh at the time of experiments. ${ }^{3}$

\section{Preparation of tissue}

Twenty-four healthy rabbits weighing from $2.5-3.0 \mathrm{Kg}$ were randomly divided into four groups $(n=6)$. We sacrificed an overnight fasting rabbit, small intestine was taken out, ileum was cut into 2 inches pieces. ${ }^{4}$ The isolated tissue was then transferred to organ bath containing tyrode's solution and aerated continuously with $95 \%$ oxygen and $5 \%$ carbondioxide. ${ }^{5}$ One end of the ileal strip was attached to the bottom of oxygen tube in tissue bath and the other end was connected to a research grade force Displacement transducer. ${ }^{6}$ After equilibration the isotonic ileal smooth muscle activity was recorded through the Displacement Transducer on Power lab. ${ }^{7}$

Group 1- Cumulative concentration response curve of Serotonin $(n=6)$

Using varying concentrations (10-9-10-6M) we construct the cumulative dose-response curves of acetylcholine. To prevent tissue sensitization new tissue was used each time $(n=6)$. This group served as a control for our study. So, fluoxetine and paroxetine mediated contractions are compared with acetylcholine induced contractions.

Group 2- Cumulative concentration-response curve of fluoxetine $(n=6)$

Fluoxetine mediated isotonic contractions were recorded using concentrations $10-9$ to $10-6 \mathrm{M}$ in the same manner as used for serotonin. ${ }^{8}$

Group 3- Cumulative concentration-response curve of paroxetine $(n=6)$

By using varying concentrations of paroxetine (10-9-10-6 M) we record the ileal smooth muscle activity in similar manner as for group 1 and 2 .

\section{Statistical analysis}

The results have been expressed as means \pm standard deviation. The arithmetic means of amplitudes of contractions and SDs were calculated using Post Hoc Tukey's test (Two-Way Anova).

\section{RESULTS}

SSRIs exert a depressive effect on contraction of ileal smooth muscles right from the beginning.

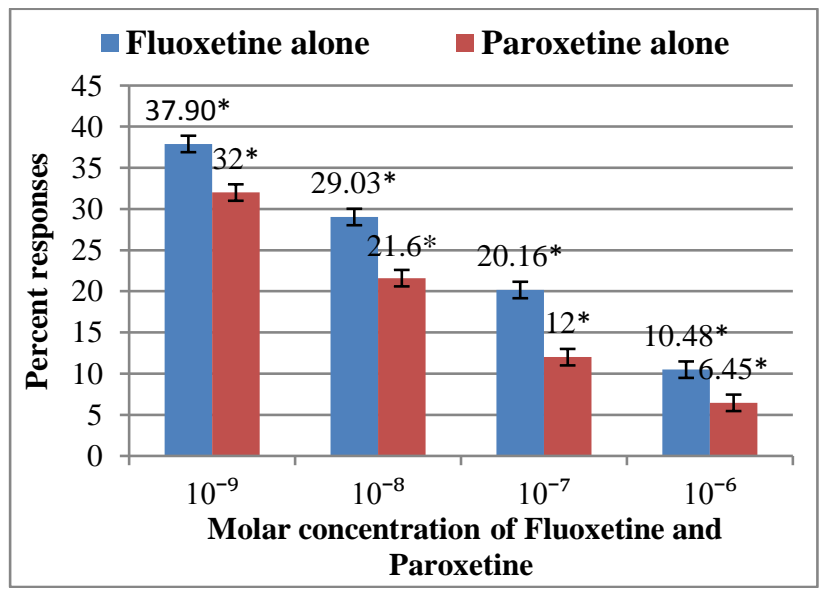

Data is represented as mean \pm standard error of means (SEM) $*=$ Significant $(\mathrm{p}<0.05)$

$=$ Non-Significant $(\mathrm{p}>0.05)$

Figure 1: Comparison of group 2 (fluoxetine) and group 3 (paroxetine) on isolated ileal smooth muscle of rabbit $(n=6)$. 
However, a significant decrease of paroxetine induced contractions was observed at $10^{-7} \mathrm{M}$ and $10^{-6} \mathrm{M}$ concentrations (Figure 1, Table 1). To evaluate the decrease in magnitude of SSRIs-induced ileal contractility we compare its response with the response of serotonin on isolated ileal smooth muscle.
Fluoxetine causes a decrease in constrictor response upto $10.53 \%$, paroxetine causes a significant decrease in ileal smooth muscle contractions from $100 \%$ (control group) to $6.45 \%$. Thus, its obvious that paroxetine has a more depressive effect on intestinal motility as compared to fluoxetine. So, fluoxetine will be a preferred antidepressant than fluooxetine as it will cause less markrd nausea and vomiting.

Table 1: Response of isolated ileal smooth muscles of rabbit to fluoxetine and paroxetine.

\begin{tabular}{|c|c|c|c|c|c|}
\hline $\begin{array}{l}\text { Concentration (M) } \\
\text { of fluoxetine }\end{array}$ & $\begin{array}{l}\text { Amplitude of } \\
\text { contractions } \\
(\text { Mean } \pm \text { SEM) } \\
\text { mm } \\
\text { control group } \\
\mathrm{n}=6\end{array}$ & $\begin{array}{l}\text { Amplitude of } \\
\text { contractions } \\
(\text { Mean } \pm \text { SEM) } \\
\text { mm } \\
\text { fluoxetine } \\
n=6\end{array}$ & $\begin{array}{l}\text { Percent }(\%) \\
\text { response } \\
\text { fluoxetine }\end{array}$ & $\begin{array}{l}\text { Amplitude of } \\
\text { contractions } \\
(\text { Mean } \pm \text { SEM) } \\
\text { mm } \\
\text { paroxetine } \\
\mathrm{n}=6\end{array}$ & $\begin{array}{l}\text { Percent }(\%) \\
\text { response } \\
\text { paroxetine }\end{array}$ \\
\hline $10^{-9}$ & $13.2 \pm 1$ & $9.4 \pm 0.453$ & 37.90 & $8 \pm 3.55$ & 32 \\
\hline $10^{-8}$ & $16.8 \pm 1.6$ & $7.2 \pm 2.09$ & 29.03 & $5.4 \pm 1.60$ & 21.6 \\
\hline $10^{-7}$ & $20 \pm 1.5$ & $5 \pm 2.095$ & 20.16 & $3 \pm 1.03$ & 12 \\
\hline $10^{-6}$ & $24.8 \pm 1.22$ & $2.6 \pm 1.16$ & 10.48 & $1.6 \pm 0.98$ & 6.45 \\
\hline
\end{tabular}

\section{DISCUSSION}

The current research study was carried out to observe the effects of Selective serotonin reuptake inhibitors (Fluoxetine and Paroxetine) on ileal smooth muscle of rabbit in vitro and to find out the possible reason that may underlies in causing severe nausea and vomiting at the start of therapy. Serotonin gradually increases the ileal smooth muscle contractility, whereas SSRIs in contrast to serotonin decreases the smooth muscle contractility. ${ }^{9}$

Serotonin by acting directly through $5-\mathrm{HT}_{4}(\mathrm{G}-$ protein coupled receptors) located on both cholinergic interneurons and motor neurons ${ }^{10}$ on enterocytes and indirectly via $5-\mathrm{HT}_{3}$ receptors on mucosal nerves and vagal afferents effects the intestinal motility. ${ }^{10}$ The $5-\mathrm{HT}_{4}$ receptors stimulation by serotonin leads to an increase in the acetylcholine release which in turn increases the intestinal activity, leading to increase in amplitude of contractions and also an increase in intestinal motility. ${ }^{11}$ Thus, serotonin mediated contractions was taken as a control in our study (100\%).

5- $\mathrm{HT}_{4}$ is responsible for relaxation of gastrointestinal tract, fluoxetine antagonizes $5-\mathrm{HT}_{4}$ the mediated responses causing decrease in contractile response of ileal smooth muscles upto $10.48 \% .^{12}$ Paroxetine causes a dose dependant decrease in the contractile activity of isolated ileal smooth muscle, in turn causing an increase in the gut transient time because of its influence on vagal and adrenergic inputs. ${ }^{13}$ In addition serotonergic receptors (5$\mathrm{HT}_{1 \mathrm{~A}}$ and $5-\mathrm{HT}_{3}$ ) they are also known to influence vagal afferents pathway and alter the reflex accommodation pathways, hence causing decrease in amplitude of contractions upto $6.45 \% .^{14-16}$
Thus, it can be deduced from our observation as well as by the studies carried out by other researchers that paroxetine has a more depressive effect on intestinal motility $(6.45 \%)$ as compared to fluoxetine $(10.48 \%))^{11-16}$ So, fluoxetine will be causing less nausea and vomiting at start of therapy than paroxetine. Fluoxetine also have the advantage of long half life (48hrs) requiring single daily dose. ${ }^{17}$

\section{CONCLUSION}

From this study, Thus, the decrease in response by SSRI's was most likely a consequence of accumulation of endogenous serotonin in vitro at the receptor site leading to desensitization.

\section{ACKNOWLEDGEMENTS}

Authors are grateful to National University of Sciences and Technology (NUST), Islamabad for providing financial support for this research study.

Funding: Funding sources from National University of Sciences and Technology Islamabad (NUST)

Conflict of interest: None declared

Ethical approval: The study was approved by the Institutional Ethics Committee

\section{REFERENCES}

1. Gregory VC, Lucki I. The role of serotonin receptor subtypes in treating depression: A review of animal studies. Psychology. 2010;213:265-87.

2. Janssen P, Oudenhove VL, Castcels C, Vos R, Verbeke K, Tack J. The effect of acute citalopram dosing on gastric motor function and nutrient tolerance 
in healthy volunteers. Aliment Ther. 2010;33:395402.

3. Mujezinovic I, Cupic V, Samajlovic A, Muminovic M. Identification of serotonergic (5-H1A-Type) receptor in broiler small intestine by application of its serotonin and antagonist. Vetnary glasnick. 2011;65(2):51-9.

4. Chial JH, Camilleri M, Burton D, Thomforde G, Olden WK, Stephens D. Selective effects of serotonergic psychoactive agents on gastrointestinal function in health. American. Journal of Physiology. Gastrointest. Liver. Physiol. 2002;284:G130-7.

5. Milne RJ, Goa KL. Citalopram a review of its pharmacodynamic and pharmacokinetic properties and therapeutic potential in depressive illness. Drug. 1991;41(3):460-77.

6. Afzal A, Ajmal K, Sabeen S. Paroxetine: An update of response on intestinal motility J Pak Med Assoc. 2016 Mar;66(3):240-2.

7. Noor A, Najmi MH, Bakhtiar S. Effect of bradykinin induced contraction on isolated smooth muscle of guniea pig. Indian Journal of Pharmacology. 2011;43(4):449-55.

8. Owens MJ, Morgan WN, Plott SJ, Nemeroff CB. Neurotransmitter receptor and transporter binding profile of antidepressants and their metabolites. J Pharmacol Exp Ther. 1997;283:1305-22.

9. Afzal A, Khan BT, Sharif M. Fluoxetine causes a decrease in intestinal motility. Int $\mathrm{J}$ Basic Clin Pharmacol. 2015;4(2):265-8.

10. Coates DM, Johnson CA, Meerveld VG, Mawe MG. Effects of serotonin transporter inhibition on gastrointestinal motility and colonic sensitivity in the mouse. Neurogastroenterol Motiity. 2006;18:464-71.
11. Jabeen Q, Aziz N, Afzal Z, Gilani HA. The spasmogenic and spasmolytic activities of lavandula Stoechas are mediated through muscarinic receptor stimulation and calcium channel blockade. International Journal of Pharmacoogyl. 2007;3(1):617.

12. James BR. Acetylcholine. Wormbook. Ed. The elegans Research Community. 2007.

13. Pithadia BA, Jain MS. 5-Hydroxytryptamine Receptor Subtypes and their modulation with Therpeutic Potentials. J of clinical Medicines Res. 2009;(1):7280.

14. Spiller R. Serotonergic modulating drugs for functional gastrointestinal diseases. British Journal of Pharmacology. 2002;54:11-20.

15. Tanko Y, Alladey O, Ahmad KM, Muhammad A, Musa KY. The effect of methanol leaves extract of Ficus Glumosa on gastrointestinal motility and castor oil induced diarrhoe in laboratory animals. Scholar research library. 2012;2(3):360-7.

16. Tuladhar RB, Costall B, Naylor JR. Modulation of 5HT4 receptor function in the rat isolated ileum by fluoxetine: the involvement of endogenous 5Hydroxytryptamine. British Journal of Pharmacology. 2002;136:150-6.

17. Wagstaff AJ, Cheer SM, Matheson AJ, Ormvod D, Goa KL. Paroxetine: an update of its use in psychiatric disorders in adults. Drugs. 2002;62(4):655-703.

Cite this article as: Afzal A, Sharif M, Khan A, Khan BT, Ara I. Effect of fluoxetine and paroxetine on intestinal motility. Int J Basic Clin Pharmacol 2018;7:429-32. 